\title{
DISPLAY JADWAL SHOLAT P7.65 BERBASIS MIKROKONTROLER ESP32
}

\author{
Rizki Priya Pratama ${ }^{1 *}$, Oktaverine Weaz Ma'arif ${ }^{2}$, Choirun Niswatin $^{3}$ \\ ${ }^{123}$ Teknik Mekatronika, Politeknik Kota Malang \\ Jl. Tlowowaru no 3, Malang, Jawa Timur. \\ *Email: rizki_priya@poltekom.ac.id
}

\begin{abstract}
Abstrak
Penelitian mengenai perhitungan jadwal sholat banyak dilakukan, baik yang berhubungan dengan cara perhitungannya hingga aplikasinya hingga dapat digunakan oleh masyarakat. Pada aplikasinya, jadwal sholat ini diterapkan pada handphone, komputer dan display LED pada masjid-masjid. Display LED ini dikontrol oleh mikrokontroler. Display LED yang ditawarkan ini menggunakan mikrokontroler ESP32, modul LED P7.65 dan RTC DS3231. ESP32 ini difungsikan sebagai webserver Jadwal Sholat dan driver modul led p7.65. Modul ESP32 diprogram menggunakan software Arduino IDE dengan menggunakan library Adzan, DMD2, RTC DS3231 dan webserver. Library Adzan digunakan untuk menghitung jadwal sholat ladzan, library DMD2 digunakan mengatur tampilan modul LED P7.65, library webserver digunakan sebagai layanan webserver Jadwal Sholat. Pada perhitungan jadwal sholat ini ditunjukkan bahwa antara perhitungan sholat dengan komputer menggunakan software Accurate Times dan mikrokontroler ESP32 mempunyai selisih kurang dari 10 detik. Selisih antara perhitungan sholat Subuh 6 detik, sholat Zhuhur, Asyar dan Isya didapatkan rata-rata selisih 5 detik, dan sholat Magrib 4 detik pertahun. Mikrokontroler ESP32 dapat melakukan fungsinya sebagai webserver Jadwal Sholat yang dapat diakses melalui webrowser smartphone android dengan baik dan juga dapat menampilkan jadwal sholat melalui modul LED P7.65.
\end{abstract}

Kata kunci: Jadwal Sholat / adzan , ESP32, DS3231, Display LED P7.65

\section{PENDAHULUAN}

Jadwal sholat 5 waktu dalam sehari merupakan hal yang sangat penting bagi umat muslim. Jadwal sholat ini dapat diketahui dengan melihat jam, akan tetapi kadang-kadang tidak yakin apakah sudah masuk waktu sholat atau belum. Hal ini dikarenakan jadwal waktu sholat setiap hari seringkali berubah-ubah. Selama ini umat muslim mengetahui waktu sholat dengan mendengar suara adzan dari mushola atau masjid terdekat. Panggilan adzan selain oleh muadzin secara langsung dapat juga diserukan melalui perangkat elektronik sebagai alat bantu pengingat waktu sholat (Nurwicaksana dkk., 2017).

Jadwal sholat juga dapat diketahui dari sebuah alat penunjuk jadwal berupa sebuah hardware sistem pengingat waktu sholat atau yang biasa digunakan dalam bentuk display berupa running text. Running text ini banyak digunakan di masjid dan mushola yang membantu takmir untuk segera melakukan persiapan mengumandangkan adzan sebagai tanda waktu sholat wajib telah tiba. Oleh karena itu, display jadwal sholat sebagai penunjuk jadwal adzan itu sangat penting (Siregar dkk., 2017).
Dahulu, jadwal sholat berupa selembar dokumen terpampang di masjid-masjid. Di antara jadwal itu ada yang usianya telah bertahun-tahun, belasan bahkan puluhan tahun. Para ahli Falak yang membuat jadwal tersebut, ada yang menamakannya jadwal sholat sepanjang masa, jadwal sholat abadi ataupun jadwal sholat untuk selama-lamanya (Jayusman, 2013). Jika kondisi jadwal sholat demikian adanya, maka apakah keakuratan jadwal sholat tersebut masih dapat digunakan sebagai pedoman penentuan waktu sholat. Apalagi jadwal waktu sholat tersebut sudah sangat lama bahkan sejak pembuatan pertama kali oleh ahli Falak (Jayusman, 2013). Hal ini memerlukan penghitungan ulang ataupun dilakukan koreksi jadwal tersebut sehingga dapat digunakan di masa sekarang.

Artikel ini akan membahas tentang penerapan algoritma adzan pada modul ESP32 dengan tampilan LED P6.75. Perhitungan algoritma ini menghitung dan mengatur jadwal sholat setiap harinya sepanjang masa.

Program algoritma ini pernah diterapkan dalam sebuah display board running text P10. Running text tersebut menggunakan mikrokontroler ARM STM32L152RB 
(Pratama, 2017).

Apabila dibandingkan dengan hardware running text diatas, running text ini menggunakan mikrokontroler ESP32 yang dilengkapi dengan fitur tambahan berupa Bluetooth dan WiFi (Espressif Systems, 2018). Fitur tambahan ini dapat mengatur tampilan pada display board running text melalui $\mathrm{WiFi}$ yang terhubung langsung dengan handphone takmir masjid, sehingga tampilan pada display board dapat diatur atau diperbarui sewaktuwaktu.

Dengan adanya display running text jadwal sholat ini, maka pengaturan jadwal sholat pada display lebih mudah karena dapat dilakukan dari jarak jauh, sehingga display running text tidak perlu diatur secara manual dan keakuratan waktu menjadi lebih tinggi sehingga bisa memimalisir selisih waktu.

Display board running text ini menggunakan modul led panel type P7.65 berwarna merah yang terdiri dari 2 led panel modul disusun atas bawah. Led panel modul ini memiliki kerapatan sebesar $7.65 \mathrm{~mm}$ sehingga tampilan display akan terlihat lebih tajam dan dapat terjangkau hingga jarak pandang 8 meter. Alat ini juga menggunakan RTC DS 3231, akurasi pada RTC type ini dicapai sebagian oleh penggabungan sensor suhu di DS3231 yang dapat mengkompensasi perubahan suhu ambient.

\section{METODE}

Perangkat running text Jadwal Sholat dalam artikel ini terdiri dari beberapa komponen utama seperti yang ditunjukkan pada Gambar 1. Modul led P7.65 merupakan tampilan utama yang digunakan sebagai penampil jadwal sholat, informasi-informasi masjid, identitas dan waktu. Modul led P7.65 dikendalikan oleh modul ESP32. Modul ini sebagai mikrokontroler untuk mengolah data, mengontrol modul led P7.65, dan melayani web Setting Jadwal.

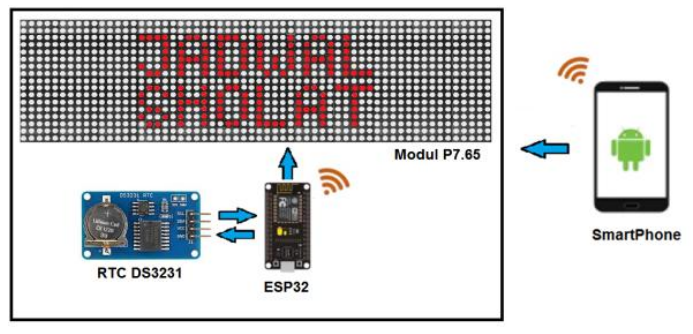

Gambar 1. Blok Diagram Alat
Modul ESP32 diprogram menggunakan software Arduino IDE dengan menggunakan library Adzan, DMD2, RTC DS3231 dan webserver. Web Setting Jadwal diprogram dengan library webserver. Web ini digunakan untuk pengaturan informasi masjid, lokasi masjid, jarak waktu iqomah, durasi waktu adzan dan jadwal adzan. Web ini diprogram dengan bahasa HTML dan Javascript yang dimasukkan ke dalam bahasa $\mathrm{C}$ seperti layaknya data string. Potongan program pengaturan waktu dapat dilihat pada Gambar 2 .

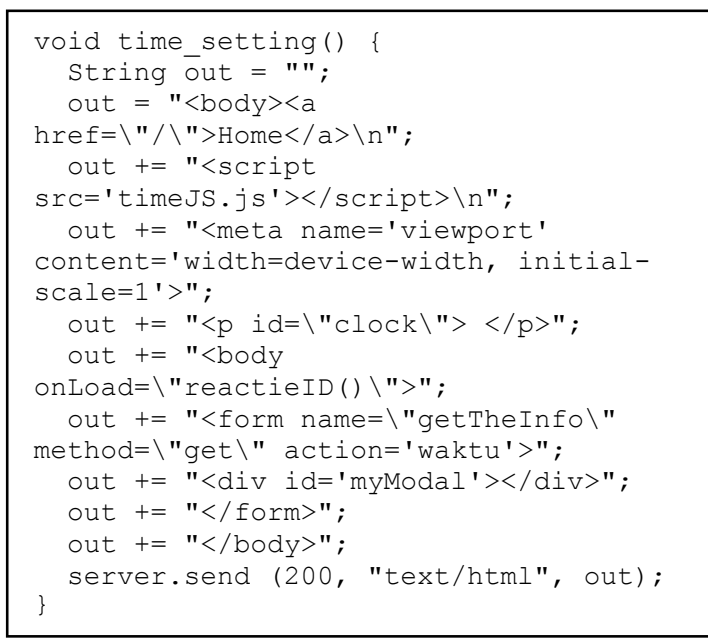

\section{Gambar 2. Potongan program pengaturan waktu.}

Library Adzan berisi rumus-rumus perhitungan matematika untuk menghitung jadwal masuk waktu sholat yang biasa disebut jadwal adzan. Terdapat beberapa variabel masukan untuk program algoritma tersebut, diantaranya koordinat garis bujur (Longtitude) dan garis lintang (Latitude) serta derajat kemiringan matahari saat terbit dan terbenam dan juga ketinggian wilayah, serta tanggal, bulan dan tahun. Variabel-variabel tersebut digunakan dalam rumus algoritma yang hasilnya berupa waktu adzan berupa jam, menit dan detik. Berikut beberapa variabel penting yang digunakan dalam perhitungan algoritma waktu sholat pada Tabel 1. 
Tabel 1. Variabel-variabel perhitungan algoritma waktu sholat

\begin{tabular}{l|l}
\hline Variabel & Keterangan \\
\hline D, M, Y & Tanggal, Bulan, Tahun \\
H & $\begin{array}{l}\text { Ketinggian DPL (dalam } \\
\text { meter) }\end{array}$ \\
Delta & Sudut Deklinasi matahari \\
ET & Equation of Time \\
Bujur & Koordinat Lintang \\
Lintang & Koordinat Bujur \\
Z & Zona Waktu \\
KA & Syafii / Hanafi \\
JD & Julian Day \\
\hline
\end{tabular}

Pada algoritma waktu sholat ini, waktu zhuhur menjadi waktu patokan karena waktu zhuhur yang berada tepat di tengah hari. Jadi untuk mendapatkan waktu sholat yang lain, hanya dengan menambahkan atau mengurangkan variabel waktu dzuhur. Hal ini dapat dilihat pada potongan program Gambar 4. Flowchart algoritma jadwal sholat dapat dilihat pada Gambar 3.

Data RTC yang merupakan waktu sekarang dan waktu sholat menjadi salah satu tampilan dari modul display P7.65. Hasil perhitungan dari algoritma adzan / library adzan diubah ke dalam data jam, menit dan detik. Data-data ini disimpan dalam sebuah array sholat[i]. Jadwal sholat ditampilkan berulang ulang beserta waktu sekarang.

Data RTC berupa waktu sekarang diambil dari RTC DS3231 dengan komunikasi I2C melalui pin 22 dan 21 modul ESP32. Library DS3231 pada Arduino IDE berperan dalam pengambilan data waktu berupa jam, menit, detik, tanggal, bulan dan tahun sedangkan library Wire berperan pada algoritma komunikasi I2C.

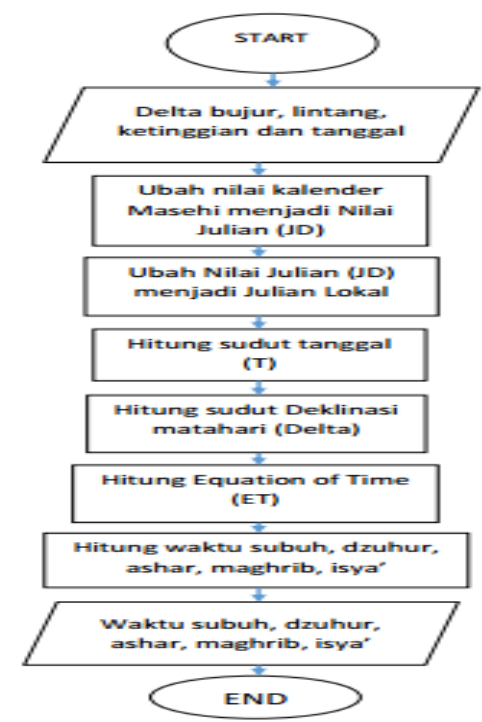

Gambar 3. Flowchart algoritma jadwal sholat

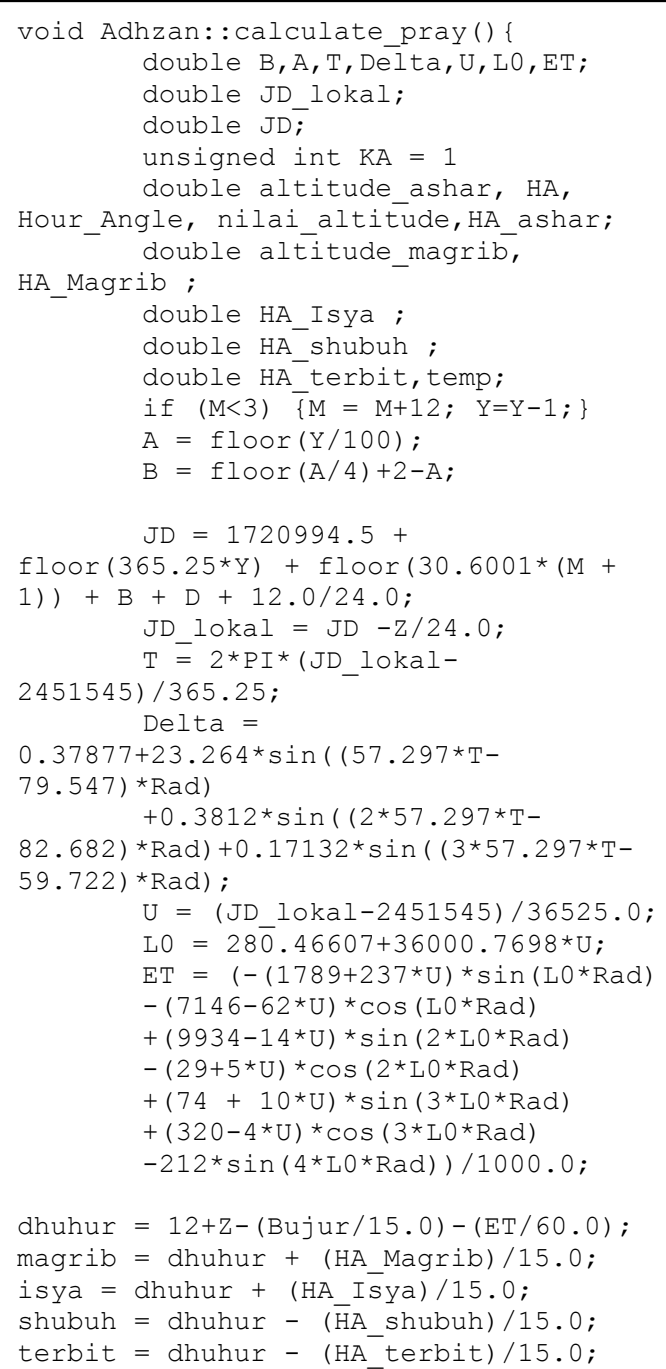

Gambar 4. Potongan potogram library Adzan. 


\section{HASIL DAN PEMBAHASAN}

\subsection{Perbandingan Jadwal Sholat}

Pengujian ketepatan jadwal sholat pada display running text dilakukan dengan membandingkan antara hasil perhitungan algoritma adzan pada modul ESP32 dengan software pada komputer yaitu "Accurate Times". Pengujian ini dilakukan dengan mengubah tanggal tertentu yang ada pada sistem perhitungan. Hasil yang ditunjukkan dengan menggunakan software Accurate Times pada tanggal 31 Agustus 2018 dapat ditunjukkan pada Gambar 5 .

Hasil perhitungan algoritma adzan pada modul ESP32 ditampilkan pada serial monitor seperti pada Gambar 6. Dari hasil diatas, dapat disimpulkan bahwa terdapat selisih 1 detik untuk waktu Zhuhur, 5 detik untuk waktu Asyar dan Magrib, 3 detik untuk waktu Isya dan 8 detik untuk waktu Subuh.

Pengujian kedua dilakukan dengan mengubah tanggal mulai dari tanggal 1 Januari hingga 31 Desember 2018 baik pada software Accurate Times maupun pada program modul ESP32. Jadwal sholat hasil dari software Accurate Times dapat dilihat pada Gambar 7, sedangkan jadwal sholat hasil dari perhitungan modul ESP32 dapat dilihat pada Gambar 8.

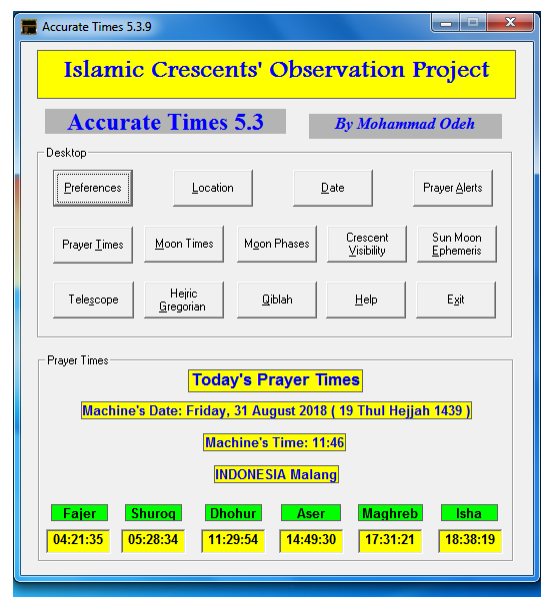

Gambar 5. Tampilan jadwal sholat pada software Accurate Times(Odeh,2016)

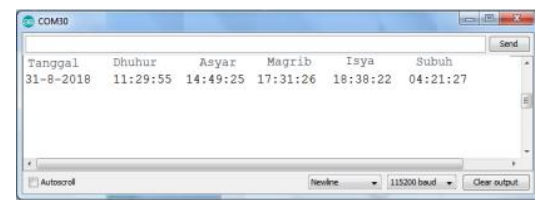

Gambar 6. Tampilan jadwal sholat pada serial monitor

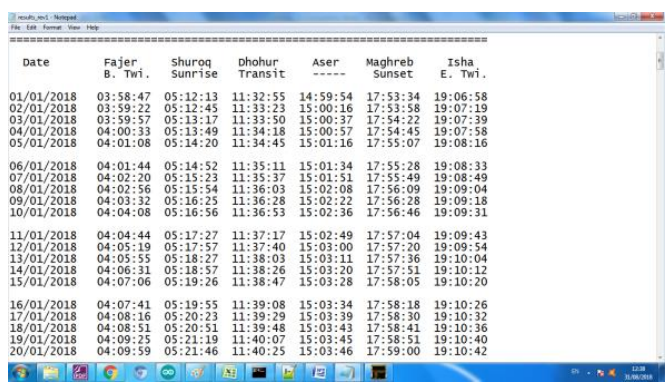

Gambar 7. Jadwal sholat hasil dari software Accurate Times

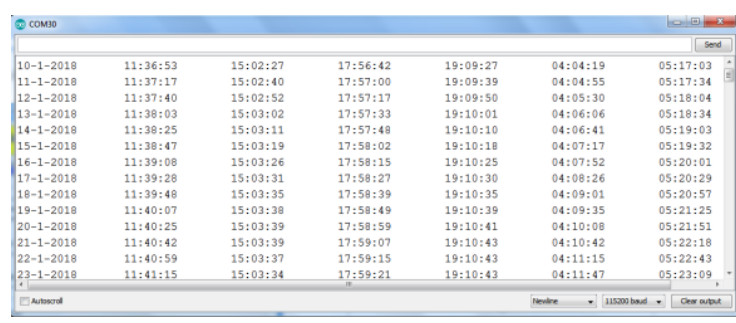

\section{Gambar 8. Jadwal sholat hasil dari perhitungan modul ESP32.}

Dari data kedua tabel tersebut kemudian diolah oleh software excel menghasilkan grafik perbandingan masing-masing sholat. Berikut adalah grafik perbandingan jadwal sholat selama 365 hari pada perangkat ESP32 dengan software Accurate Times, untuk warna biru menunjukkan grafik data pada ESP32 dan warna merah merupakan grafik data pada software Accurate Times.
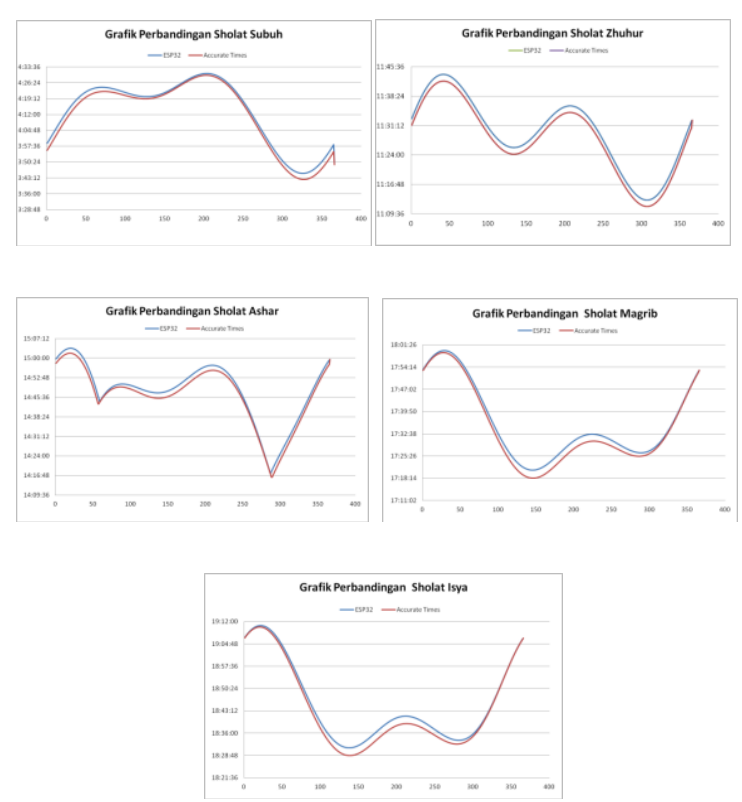

Gambar 8. Grafik perbandingan sholat dengan software Accurate Times 
Dari grafik gambar 8 didapatkan selisih antara perhitungan software Accurate Times dan modul ESP32. Selisih ini ditampilkan pada grafik Gambar 9. Pengamatan grafik Gambar 18 disimpulkan bahwa rata-rata selisih 5 detik untuk waktu Zhuhur, Asyar dan Isya, 4 detik untuk waktu Magrib dan 6 detik untuk waktu Subuh. Hasil kesimpulan ini dapat dilihat pada Tabel 2.

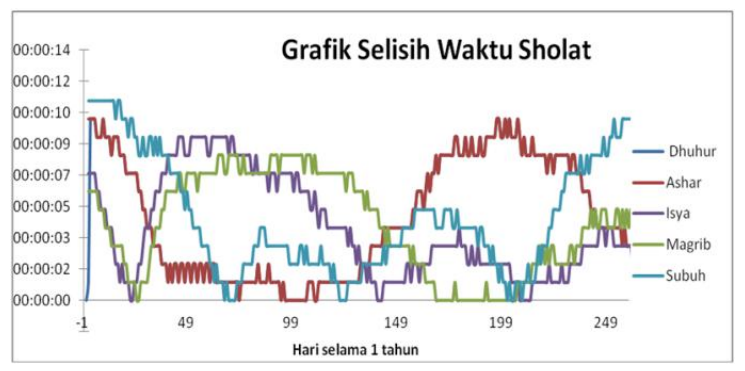

Gambar 9. Grafik selisih waktu sholat antara perhitungan software Accurate Times dan modul ESP32

Tabel 2. Variabel-variabel perhitungan algoritma waktu sholat (detik)

\begin{tabular}{ccc}
\hline Waktu & Selisih terbanyak & Selisih Rata-rata \\
\hline Zhuhur & 10 & 5 \\
Asyar & 10 & 5 \\
Magrib & 8 & 4 \\
Isya & 10 & 5 \\
Subuh & 12 & 6 \\
\hline
\end{tabular}

\subsection{Tampilan Web Jadwal Sholat}

Tampilan jadwal sholat juga dapat dilihat pada web Setting Jadwal melalui smartphone seperti pada Gambar 10a. Tampilan Jadwal Sholat ini merupakan hasil perhitungan jadwal pada modul ESP32 yang ditampilkan pada webrowser. Pada laman ini, terdapat beberapa pengaturan antara lain Time, Atur Jadwal, Lokasi Masjid dan Pesan Masjid.

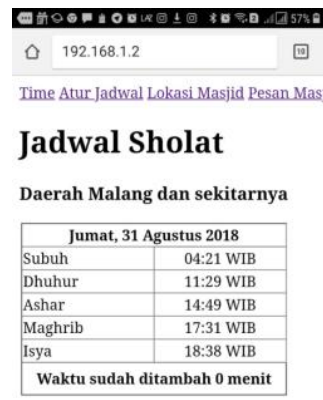

a

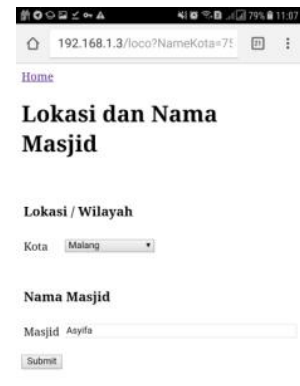

b
Gambar 10. Tampilan jadwal sholat pada smartphone dan Menu setting
Menu Atur Jadwal digunakan untuk mengatur perhitungan terbit, durasi waktu adzan, koreksi waktu adzan, dan setting jarak iqomah. Menu Atur Jadwal dapat dilihat pada Gambar 11. Pada menu ini jadwal sholat dapat dikurangi dan ditambahkan sesuai dengan kesepakan para takmir. Selain itu juga, terdapat menu pengaturan jarak iqomah yang digunakan untuk memberikan waktu beberapa menit setelah adzan sehingga para jama'ah dapat melakukan sholat sunnah. Jarak waktu antara iqomah dan adzan dapat diatur sesuai dengan kebutuhan dan keperluan dalam masjid tersebut.

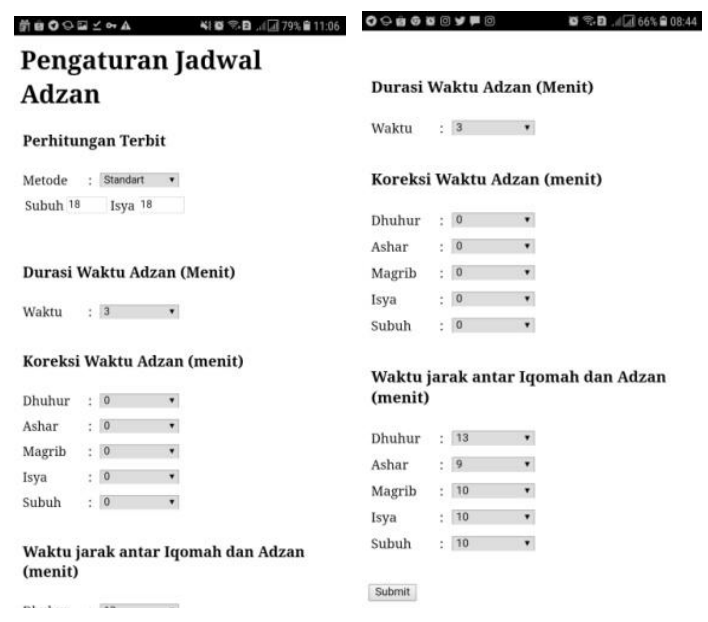

\section{Gambar 11. Menu setting untuk mengatur waktu adzan}

Pengaturan lokasi masjid sangat diperlukan karena lokasi masjid menentukan jadwal waktu sholat / adzan tersebut, lokasi masjid digunakan untuk menentukan garis litang (latitude) dan garis bujur (longtitude) seperti pada Gambar 10b. Pada menu ini terdapat lebih dari 100 daerah di Indonesia. Tulisan pengumuman dapat disampaikan oleh takmir sewaktu-waktu melalui Gambar 12. Menu Time digunakan untuk menyamakan waktu di display masjid dengan waktu pada smartphone.
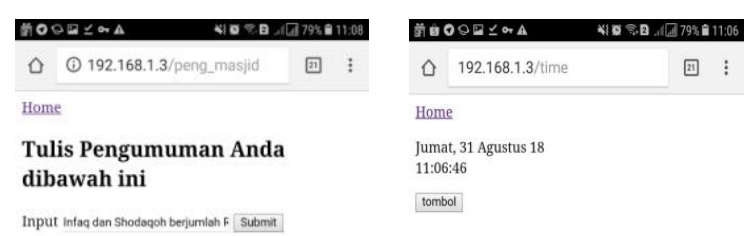

Gambar 12. Menu setting untuk memasukkan pesan dan singkron waktu. 


\subsection{Tampilan Display LED}

Display jadwal sholat akan aktif menampilkan beberapa informasi satu jam sebelum dan sesudah waktu adzan. Informasi yang ditampilkan berupa jadwal-jadwal sholat, tampilan informasi hadist, jam dan tanggal, serta informasi / pengumuman dari takmir. Jadwal sholat ini akan terus menerus ditampilkan secara bergantian seperti pada Gambar 13 dibawah ini. Sedangkan tampilan informasi yang berupa text berjalan / running text dapat dilihat pada Gambar 14.

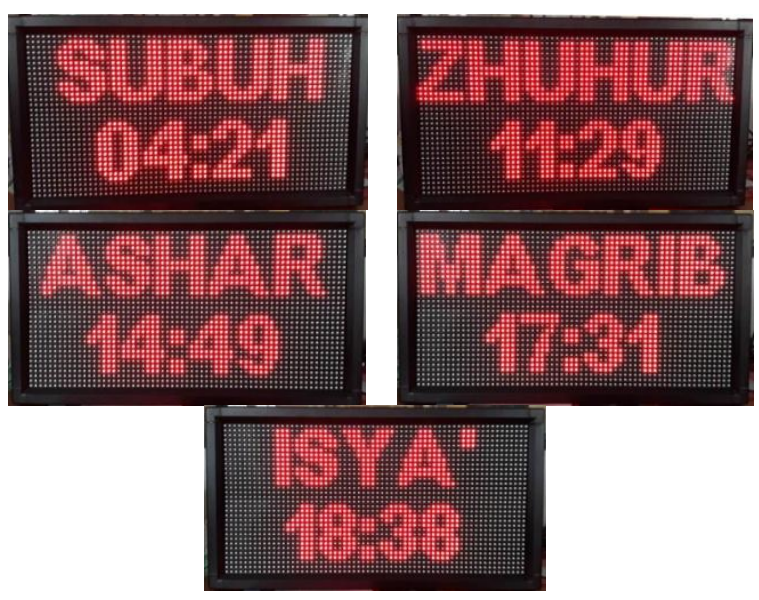

Gambar 13. Tampilan Jadwal Adzan setiap sholat
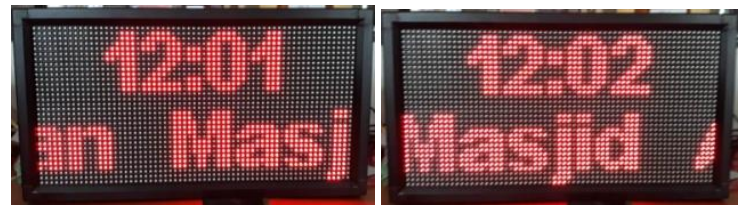

\section{Gambar 14. Tampilan tulisan berjalan}

Tampilan jarak iqomah akan menghitung mundur dari waktu setelah adzan ke waktu iqomah. tampilan tersebut dapat dilihat pada Gambar 15.
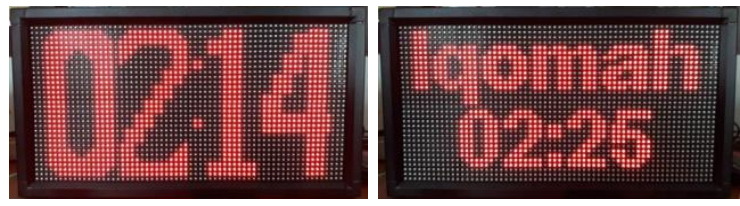

\section{Gambar 15. Tampilan hitungan mundur waktu Iqomah.}

\section{KESIMPULAN}

Pada perhitungan jadwal sholat ini ditunjukkan bahwa antara perhitungan sholat dengan komputer menggunakan software Accurate Times dan mikrokontroler ESP32 mempunyai selisih kurang dari 10 detik. Selisih antara perhitungan sholat subuh 6 detik, sholat zhuhur, asyar dan isya didapatkan rata-rata selisih 5 detik, dan sholat magrib 4 detik pertahun.

Mikrokontroler ESP32 dapat melakukan fungsinya sebagai webserver Jadwal Sholat yang dapat diakses melalui webrowser smartphone android dengan baik dan juga dapat menampilkan jadwal sholat melalui modul LED P7.65.

\section{DAFTAR PUSTAKA}

Nurwicaksana, Riskitasari, Pamenang, Adhisuwignjo, 2017. Alat Pengingat Waktu Sholat di Masjid Berbasis Raspberri Pi, Seminar Nasional Teknologi dan Informatika (SNATIF 2017) ISBN: 978-602-1180-50-1, Kudus.

Siregar, Jabbar, Usman, 2017. Perancangan Perangkat Keras Sistem Pengingat Waktu Sholat Elektronik. Internet : http://journal.stth-medan.ac.id[Sept. 29, 2018].

Jayusman, Maret 2013. Jadwal Waktu Salat Abadi, Jurnal Katulistiwa-Journal of Islamic Studies, Vol. 1, No.1, Maret 2013.

Pratama, Rizki Priya, April 2017. Perhitungan Jadwal Sholat pada ARM Cortex STM32L152RB, Jurnal Invotex, vol.17, No.1, April 2017.

Espressif Systems, 2018. ESP32 Series Datasheet, https://www.espressif.com.

Odeh, Muhammad. 2016. Software Acurate Times. 